\title{
Çocuğu Tanıma ve Değerlendirme Aracı Olarak Pedagojik Dokümantasyon
}

\section{Pedagogical Documentation as a Child Recognition and Evaluation Tool}

\section{Nilüfer KURU*}

\author{
Berrin AKMAN**
}

Received: 02 May 2018

Review Article

Accepted: 25 June 2019

\begin{abstract}
Early childhood has a critical prescription for recognizing and evaluating the child. In this period, it is possible to present learning experiences that are appropriate for the development characteristics, interests and needs of children, but only if the child is correctly recognized. A child can only be referred to without a proper assessment after being sufficiently recognized. In this study, the pedagogical documentation process which deals with the development and learning process of the child with a holistic approach is mentioned. Pedagogical documentation practices that encourage children to interrogate, think, communicate, take responsibility for their own learning, and curiosity and exploration also allow teachers to develop themselves. It is important that pedagogical documentation is used as a tool in preschool education in terms of supporting all development areas of children, creating a secure bond between teacher, child and family, developing positive communication and supporting the involvement of the family in the learning process. In the study of general and descriptive information about documentation; the stages of the documentation, the importance of the child, the teacher and the family, the types of documentation, the documentation process, and finally the process of understanding the documentation of the teachers.
\end{abstract}

Keywords: pedagogical documentation, recognition and evaluation, early childhood.

ÖZ: Erken çocukluk dönemi, çocuğu tanıma ve değerlendirme açısından kritik öneme sahiptir. Bu dönemde çocukların gelişim özelliklerine, ilgi ve ihtiyaçlarına uygun öğrenme deneyimleri sunulması ancak çocuğun doğru bir şekilde tanınması ile mümkündür. Çocuk, ancak tüm gelişim alanları ile tanındıktan sonra doğru bir değerlendirmeden söz edilebilir. Bu çalışmada çocuğun gelişim ve öğrenme sürecini bütüncül bir yaklaşımla ele alan pedagojik dokümantasyon sürecine değinilmiştir. Çocukları sorgulamaya, düşünmeye, iletişim kurmaya, kendi öğrenmelerinin sorumluluğunu almaya, merak ve keşfetmeye güdüleyen pedagojik dokümantasyon uygulamaları, aynı zamanda öğretmenlerin de kendilerini geliştirmelerine imkân tanımaktadır. Pedagojik dokümantasyonun çocukların bütün gelişim alanlarını desteklemesi, öğretmen, çocuk ve aile arasında güvenli bağ oluşturması, olumlu iletişimi geliştirmesi, ailenin çocuğun öğrenme sürecine dâhil edilmesine destek olması, öğretmenin kendini değerlendirmesine firsat sunması, çocuğun öğrenme sürecine etkin katılımını sağlaması gibi yönleri ile okul öncesi eğitimde bir araç olarak kullanılması önemli görülmektedir. Pedagojik dokümantasyon hakkında genel ve açıklayıcı bilgilerin yer aldığı çalışmada; dokümantasyonun evrelerine, çocuk, öğretmen ve aile açısından önemine, dokümantasyon türlerine, dokümantasyon sürecine, öğretmenlerin dokümantasyonu anlama süreçlerine ve okul öncesi dönemde pedagojik dokümantasyonun yeri ve önemine değinilmiştir.

Anahtar kelimeler: pedagojik dokümantasyon, tanıma ve değerlendirme, erken çocukluk.

\footnotetext{
* Corresponding Author: Res. Asst., Siirt University, Siirt, Turkey, nilferkuru@gmail.com, https://orcid.org/00000003-4237-9349

** Prof. Dr., Hacettepe University, Ankara, Turkey, bakman@hacettepe.edu.tr, https://orcid.org/0000-0001-56684382
}

Citation Information

Kuru, N., \& Akman, B. (2019). Çocuğu tanıma ve değerlendirme aracı olarak pedagojik dokümantasyon. Kuramsal Eğitimbilim Dergisi [Journal of Theoretical Educational Science], 12(3), 935-949. 


\section{Giriş}

"Çocuklar, başardıkları şeyin

anlamı üzerine düşündüklerinde ve kafa yorduklarında çok daha meraklı, ilgili ve kendilerine güvenli olmaya başlarlar” (Malaguzzi, 1998).

Erken çocukluk döneminde çocuğun gelişimini desteklemek ve çevreye adaptasyonunu sağlamak adına yapılan girişimler ancak çocuğu tanımakla mümkündür. Erken çocukluk hizmetlerinden çocukların maksimum fayda sağlaması için öğretmenlerin çocuğun; gelişim özellikleri, ailesinin sosyo-kültürel ve ekonomik düzeyi, ilgi, beceri, tutum, kişilik özellikleri, akran ilişkileri gibi davranışsal özellikleri ile güçlü ve geliştirilmesi gereken yönleri hakkında yeterli ölçüde bilgi sahibi olması gereklidir.

Çocuğu tanıma süreci çok yönlü bir süreçtir. Bu süreçte çocuğa ilişkin elde edilen bilgilerin gizliliği, çocuğu tanıma hizmetlerinin farklı ortamlarda ve zamanlarda sürekli devam etmesi, çocuğu tanırken tek bir araçtan elde edilen bilgiler yerine amaca uygun birden çok kaynağın kullanılması, çocuğu tanımaya yönelik elde edilen bilgilerin objektif değerlendirilmesi oldukça önemlidir (Akman, 2013; Mesleki Eğitim ve Öğretim Sisteminin Güçlendirilmesi Projesi [MEGEP] 2015). Çocuğu tanıma ve değerlendirme sürecinde öğretmenler çocukların yapamadıkları üzerine yoğunlaşmamalı, çocukların davranışlarının sonuçlarından çok o davranışın gerçekleşme sürecine ve nedenine odaklanmalı, çocuklar arasındaki bireysel farklılıkları göz ardı etmemeli, değerlendirme çalışmalarını mutlaka etik çerçevede yürütmelidir (MEGEP, 2015). Özellikle okul öncesi dönemde çocukların gelişimlerinin oldukça hızla olması ve bu dönemde gerçekleşen öğrenmelerin, gelecekteki bilgi ve becerilerin temelini oluşturması açısından çocukların doğru tanınmaları ve değerlendirilmeleri çok önemlidir (Alkan \& Kurt, 2014). Çocukların tüm özellikleri ile tanınması ve bu amaca uygun eğitimle gelişimlerinin desteklenmesi, hem çocukların kendilerini değerlendirmelerine, hem de aile ve öğretmenlerin değerlendirilmelerine imkan tanıyarak verilen eğitimin kalitesine de dikkat çekmektedir (Deniz-Kan, 2007; Gullo, 2005). Bu nedenlerle okul öncesi dönemde çocuğu tanıma ve değerlendirmede kullanılacak araç ve yöntemlerin seçimi oldukça önemlidir. Okul öncesi dönemde pedagojik dokümantasyonun önemine ilişkin yapılan çalışmalar incelendiğinde; Buldu, Şahin ve Yılmaz (2018), çocukların farklı gelişim alanlarında pedagojik dokümantasyonun katkılarını öğretmen bakış açısından ele aldıkları araştırmalarında, öğretmenler dokümantasyon sürecinin, çocukların sorumluluk alma isteklerini, kendini değerli hissetme duygularını, çocuklar arası etkileşimi arttırdığını ve ayrıca pedagojik dokümantasyonun çocukların dil gelişimlerinin geliştirilmesine de katkı sağladığını belirtmişlerdir. Benzer şekilde araştırma sonuçları pedagojik dokümantasyonun, çocukların öğrenmeye ilişkin ilgi, istek ve motivasyonlarını arttırdığını, çocukların matematiksel düşüncelerinin anlaşılmasına imkan tanıdığını, çocukların hatırlama becerilerini geliştirdiğini ayrıca öğretmen ve aile arasındaki etkileşimi de desteklediğini göstermiştir (Buldu, 2010; Fleck Leichtman, Pillemer, \& Shanteler, 2013; McLellan, 2010). MacDonald (2006) tarafından yapılan araştırmada pedagojik dokümantasyon aracılı̆̆ı ile öğretmenlerin ve ebeveynlerin; çocukların ilgi alanları, merakları ve güçlü yönleri hakkında daha derin bir anlayış geliştirdikleri sonucuna ulaşmıştır. Bowne, Cutler, DeBates, Gilkerson, \& Stremmel, (2010), çocukların öğrenmelerinin öğretmenler tarafından belgelenmesinin, öğretmenlerin çocukları daha iyi anlamalarına, anlamlı bir müfredat geliştirmelerine, 
sorgulamaya öncülük etmelerine katkı sağlayacağını, bireysel ve grupla öğrenmede pedagojik dokümantasyonu kullanılmasının ise profesyonel gelişimi destekleyeceğini belirtmişlerdir. Rintakorpi ve Reunamo (2017), erken çocukluk eğitiminde pedagojik dokümantasyonun çocuklarla birlikte yürütülecek olan etkinliklerin dikkatlice planlanması ile yakından ilgili olduğunu, pedagojik dokümantasyonun çocukların yaratıcılıklarını, eğlenerek öğrenmelerini, pozitif duygusal süreç geçirmelerini, etkinliklere yüksek düzeyde katılımlarını, öğretmenler ve çocuk arasında güvenli bağ oluşumunu desteklediğini belirtmişlerdir. Alan yazın incelendiğinde özellikle okul öncesi dönemde çocukların gelişim ve öğrenmeleri üzerinde oldukça etkili olan pedagojik dokümantasyona ilişkin yapılmış olan çalışmaların oldukça sınırlı olduğu görülmüştür. Özellikle ulusal yayınların oldukça az olması pedagojik dokümantasyona ilişkin derinlemesine bilgi vermeyi amaçlayan bu araştırmayı önemli kılmaktadır (Buldu, 2010; Buldu, Şahin, \& Y1lmaz, 2018; Fleck ve ark. 2013; McLellan, 2010). Çalışmada, çocuğu tanıma ve değerlendirmede kullanılan yöntemler arasında bulunan pedagojik dokümantasyona ilişkin derinlemesine bilgi sunmak amaçlanmıştır. Bu amaç doğrultusunda, pedagojik dokümantasyonun evrelerine, çocuk, öğretmen ve aile açısından önemine, pedagojik dokümantasyon türlerine, pedagojik dokümantasyon sürecine, öğretmenlerin pedagojik dokümantasyonu anlama süreçlerine ve son olarak ise okul öncesi dönemde pedagojik dokümantasyonun yeri ve önemine değinilmiştir.

\section{Pedagojik Dokümantasyon}

Erken çocukluk öğretmenleri, çocukların gelişimlerini değerlendirmek ve eğitim sürecini planlamak için uzun yıllardır gözlem ve dokümantasyon tekniklerini kullanmaktadır. Ulusal Küçük Çocukların Eğitimi Derneği [NAEYC] (2001), "eğitim ve öğretim sürecine küçük çocukların etkili bir şekilde katılımının sağlanmasının, her çocuğun kendine özgü niteliklerinin, güçlü yönlerinin ve gereksinimlerinin objektif bir şekilde gözlemlenmesi ve belgelenmesiyle başladığını" belirtir. Gözlem, dokümantasyon ve yorumlama süreci sayesinde, öğretmen çocuğun düşünce biçimi hakkında fikir edinir. Çeşitli deneyimlerle iç içe olan çocukların sürekli ve sistemli bir şekilde gözlemlenmesi, çocuğun gelişim düzeylerinin, ilgi alanlarının, problem çözme stratejilerinin, becerilerinin ve başarısının yanında kişiliğinin ve mizacının da gerçek bir resmini sunar (Forman \& Hall, 2005).

Okul öncesi eğitim sınıflarında, öğretmenler çocukların nasıl geliştiği ve karşılaştıkları firsat ve engellere nasıl cevap verdikleri hakkında fikir edinmek için gözlem ve dokümantasyonu kullanır. Süreç boyunca devam eden gözlemsel değerlendirme, erken çocukluk öğretmenlerinin çocukların kaydettiği ilerlemeler hakkında bilinçli kararlar vermelerini sağlar. Bu nedenle dokümantasyon yoluyla yıllar boyunca erken çocukluk programlarında öğretmenler, keskin gözlemci olmaları, atipik davranışları tanımaları ve bütün öğrencilerin öğrenmesine hizmet eden çeşitli gözlem ve belgeleme tekniklerini kullanmaları yönünde teşvik edilmiştir (Beaty, 2006).

Öğretmenler uygun müfredatı planlamak ve bilgi vermek amacıyla çocuğun daha kapsamlı bir şekilde değerlendirilmesine fırsat veren gözlemlerinden bilgi edinir (Darling-Hammond \& Bransford, 2005; Jablon, Dombro, \& Dichtelmiller, 2007) ve böylece öğretmenler tarafından çocuğun yakınsak gelişim alanı tanımlanır (Chen \& McNamee, 2006). Reggio Emilia okul öncesi eğitimi sınıflarında uygulanan dokümantasyon türleri, birçok okul öncesi öğretmenine, çocukların günlük etkinlikleri 
sırasında yaşadıkları deneyimlere, hatıralara ve düşüncelere daha yoğun bir şekilde odaklanmaları konusunda ilham vermektedir. Gözlem ve "pedagojik" belgeler pedagojiyi pratiğe yansıtma araçlarıdır ve Reggio Emilia okullarında aynı zamanda yaklaşımın önemli bir parçasını da oluşturmaktadır. Pedagojik dokümantasyon belgeleri önceden belirlenmiş beklentiler veya normlar olmadan çocuğun etkinlik sürecinde neler olup bittiğini, çocuğun neleri yapabildiğini veya geliştirilmesi gereken yönlerini görmeye ve anlamaya da firsat vermektedir. Pedagojik dokümantasyon, Reggio Emilia okullarındaki öğretmenlerin çocuklara saygılı, esnek fakat kapsamlı bir müfredat planları geliştirmelerine yardımcı olan bir araçtır. Öğretmenler çocukları farklı bağlamlarda gözlemlerken, çocukların ilgi alanlarını, gelişim ve beceri düzeylerini ve çocukların karşılaştıkları sorunları çözmek için kullandıkları stratejileri keşfederler (Forman \& Hall, 2005). Pedagojik dokümantasyon, çocukları çalışmalarını tekrar ziyaret ettiklerinde ve etkinlik süreçlerini düşündüklerinde daha meraklı ve kendinden emin olmaları için teşvik eder (Malaguzzi, 1998). Pedagojik dokümantasyon yalnızca çocukların çalışmasını değil aynı zamanda öğretmenin çalışmasını da karakterize eder. Öğretmenler arası işbirliği, çocukların bilgi birikimini araştırıp birbirlerine yansıttıkları süregelen bir süreçtir. Böylece pedagojik dokümantasyon öğretmenin araştırması, yansıtması, işbirliği yapması ve karar vermesi için bir araç haline gelir. Bu süreçte öğretmenler de mesleki gelişimlerinin en ilginç ve en gelişmiş anlarını dokümante ederek belgelemiş olurlar. Süreç içerisinde pedagojik dokümantasyon, çocuklar için olumlu deneyimlerin oluşturulması ve yetişkinler için de profesyonel gelişimin ve iletişimin kolaylaştırılması için vazgeçilmez bir araç halini almaktadır (Alcock, 2000; Seitz, 2008). Pedagojik dokümantasyon aracılığı ile çocukların günlük hayatlarındaki şaşırtıcı keşifler ve okulda yaşadıkları sıra dışı olaylar üzerinde düşünmek ve bunları açıklamak üzere gözlem ve kayıtta bulunmaya yönelik maksatlı bir tercihte bulunma süreci gerçekleşmektedir. Bu süreçte öğretmenlerin farklı bakış açılarıyla çeşitli araçları kullanarak yürüttükleri hassas gözlemlerinin dikkatlice yorumlanması oldukça önemlidir (Dahlberg, Moss, \& Pence, 2006; Kinney \& Wharton, 2008). Öğrenmeye yönelik, kendi fikirlerini, kuramlarını ve stratejilerini geliştirme girişimlerinde bulunan çocukların, gözlemleri ve çalışmaları hakkında öğretmenlerin ve ebeveynlerin derinlemesine bilgi sahibi olmaları gereklidir. Çocuklara, öğretmenler ve ebeveynler tarafindan bu desteğin verilebilmesi için kullanılabilecek en güçlü araçlardan biri ise, onlara bir birey olarak saygı duyan pedagojik dokümantasyondur. Aşağıda belirtildiği gibi genel olarak altı evreden oluşan pedagojik dokümantasyonun, evreler ile öğrenilen, kolaylaşan ve aşamalı olarak gerçekleştirilen bir süreç olduğu gerçeği göz ardı edilmemeli ve dokümantasyon sürecinde mutlaka bu evrelere dikkat edilmelidir (Alcock, 2000; Dahlberg, Moss, \& Pence, 2006; Seitz, 2008):

1. Pedagojik dokümantasyona karar verme: $\mathrm{Bu}$ evrede, öğretmenler neleri dokümante edeceği sorusunu kendisine sorar. Her çocuktan eşitlik ilkesine önem vererek çocukların çalışmaları toplanır ve bu çalışmalarla zengin içerikli panolar hazirlanır.

2. Teknoloji kullanımını keşfetme: Öğretmenler çeşitli etkinliklerden ve deneyimlerden elde edilen araçları ve fotoğrafları nasıl kullanacağını keşfeder. Fotoğrafların çoğu bülten panolarında veya albümlerde sergilenir. Hazırlanan video kayıtlarını slayt gösterisi şeklinde aileler ve çocuklar ile paylaşır. 
Öğretmenler teknoloji hakkında yeterli bilgiye sahip olabilmek için araştırmalar yapar ve gelişmeleri takip eder.

3. Çocukların katılımına odaklanma: Öğretmenler bu evrede, öğrenme süreci içinde çocukları yansıtan fotoğraflar çekmeyi öğrenirler. Böylece öğretmenler, teknolojik olarak donanımlı hale gelir ve önemli öğrenme olaylarına ve deneyimlerine odaklanabilirler.

4. Bilgi edinme: Öğretmenler fotoğrafların, etkinliklerin ve deneyimlerin başlığını atarak çocukların öğrenme hikâyelerini anlatan açıklamalar yazmaya başlar. Bu durum öğretmenlerin çocukların çalışmaları ve deneyimleri arasında bağlantı kurmasina destek olur.

5. Bağlantı kurma ve hikâye anlatma: Öğretmenler, tüm öğrenme sürecini desteklemek için çalışma örneklerini, fotoğrafları, açıklamaları ve çeşitli bilgileri birleştirir. Bütün bu süreci giriş, gelişme ve sonuç olarak hikâye şeklinde sunar. Öğretmen pedagojik dokümantasyonu çocukların eylemleri, deneyimleri ve program arasında bağlantı kurmak için kullanır.

6. Karar alma: Öğretmenler, pedagojik dokümantasyon yoluyla, sorular sorar, yansımalarda bulunur, değerlendirme yapar ve teoriler üretir. Bu süreç sonunda öğretmenler anlamlı eylemleri/olayları belgeleyen, neden önem taşıdıklarını açıklayan, yansıtıcı uygulayıcılar haline gelir ve kendilerini ve başkalarını bu deneyimleri düşünmeye devam etmeye zorlar.

Pedagojik dokümantasyonun başarılı bir şekilde yapılması için öğretmenlerin, dokümantasyonun evrelerini, neyin gözlemleneceğini ve bilgi toplamak için ne yapılacağını iyi bilmeleri önemlidir (Seitz, 2008). Pedagojik dokümantasyonun etkili bir şekilde yürütülebilmesi zaman ve deneyim gerektirir. Öğretmenler öğrenmeye dair edindikleri bilginin neden önemli olduğunu kavradıkça çocukların gelişim ve öğrenme süreçleri hakkında değerlendirme yapmalarının önemini kavrarlar (Edwards \& Gandini, 2001). Öğretmenler bu süreç içerisinde toplanan bilginin en iyi şekilde nasıl yorumlanacağını ve sunulacağını ögrenerek çocuklar hakkında edindiği önemli ve kritik bilgileri eğitim programı ve öğretim planına entegre ederler (Seitz, 2008; Alcock, 2000). Pedagojik dokümantasyonu daha iyi anlayabilmek için, dokümantasyonun yalnızca öğretmen açısından değil çocuk ve aile açısından da öneminin anlaşılması oldukça önemli görülmektedir.

\section{Çocuk Açısından Pedagojik Dokümantasyonun Önemi}

Pedagojik dokümantasyon, çocukların kendi oluşturdukları ürünler aracılığı ile öğrenme yaşantılarını ve öğrenme süreçlerini derinleştirmelerine katkı sağlar. Loris Malaguzzi, "çocuklar, başardıkları şeyin anlamı üzerine düşündüklerinde ve kafa yorduklarında çok daha meraklı, ilgili ve kendilerine güvenli olmaya başlarlar" (Malaguzzi, 1998) diyerek dokümantasyonun önemini vurgulamıştır. Pedagojik dokümantasyon, çocukların neyi nasıl öğrendiklerine odaklanarak gelişim süreçlerini görünür kılmayı amaçlamaktadır (Dahlberg ve ark., 2007). Pedagojik dokümantasyon hazırlama sürecinde çocuklar, edindikleri bilgileri derinleştirip sorgulayarak kalıcı hale getirirken aynı zamanda hem bireysel hem de akranları aracılığı ile çeşitli öğrenmeler de gerçekleştirirler (Buldu ve ark., 2018). Dokümantasyon sürecinde, çocukların fikirlerini, düşüncelerini, duygularını içeren dokümanların oluşturulması, çocukların önemli deneyimlerini içeren öğrenme süreçlerinin tekrar hatırlanabilmesi açısından da çok 
önemlidir (Kline, 2008). Pedagojik dokümantasyonun problem kurma ve problem çözmeye dayalı uygulamaları, çocukların merak duygusunu arttırarak sorgulama yapmalarına olanak tanır (Fleck ve ark. 2013; Kline, 2008; MacDonald, 2007). Dokümantasyon sürecinde çocuklar araştırmacı rolleriyle bilgiye eleştirel yaklaşarak bilgiye ulaşma yolunda farklı kaynaklar araştırıp teoriler üretir, yaşıtları, öğretmenleri ve aileleriyle paylaşır böylelikle bu süreçte çocukların kendilerine olan güvenleri pekişir (Reynolds \& Duff, 2016). Çocukların hem evde hem de okulda öğrendikleri bilgileri ve yaşadıkları deneyimleri paylaşmaları aynı zamanda kaliteli bilgi akışını da sağlamış olur (Dahlberg, Moss, \& Pence, 2007; Kline, 2008; MacDonald, 2007).

Dokümantasyonların paylaşılması, çocukları düşünmeye sevk ederek, öğrenmeye karşı istek uyandırmaları ve başka konulara dâhil olmaları konusunda motive eder (MacDonald, 2007). Çocukların öğrenme süreçlerini içeren pedagojik dokümantasyon araçları (panel, portfolyo, bülten) aynı zamanda çocukların nasıl bir öğrenme sürecinden geçtiklerini, bu süreç boyunca göstermiş oldukları çabalarının ve fikirlerinin dikkate alındığını görmelerine ve çocuğun kendini değerli hissetmesine de katkı sağlamış olur. Pedagojik dokümantasyon sürecinde öğrenmeyi görünür kılmak için panel, portfolyo ve bülten kullanılmaktadır. Çocukların alan gezileri öncesi ya da sonrasında yapmış oldukları resimleri içeren posterler, çocuk grupları tarafından yürütülen etkinlikler, çocuklar ve öğretmenler tarafından oluşturulan metinleri içerebilen duvar dokümantasyon panelleri, Reggio Emilia'da öğrenme merkezlerinin ve sınıf ortamının önemli bir parçasıdır. "Konuşan duvarlar" olarak da adlandırılan pedagojik dokümantasyon panelleri, bilgi vermekten daha çok eğitici olma özelliği taşımaktadır (Thornton \& Brunton, 2014). MacDonald (2007) dokümantasyon panellerinin "dünyaya etki eden" bir sürecin parçası olarak görülebileceğini ifade etmiştir. Dokümantasyon panelleri çocuğu, "öğrenme" ile ilgili davranışın önemli yönlerini dikkate almaya yöneltip, öğrenmeyi görünür kılmaktadır. Paneller aracılığı ile çocuklar, kendilerini yönetebilmekte ve etkinlik sürecini somut hale getirilebilmektedir. Böylece dikkatlice tasarlanmış paneller, çocukların keşiflerine ilişkin bir dizi otantik değerlendirme sağlamaktadır. Çocukların bütünsel gelişimi hakkında bilgi sağlayan portfolyolar da pedagojik dokümantasyonun en önemli bileşenlerinden biridir. Okul, çocuk, aile ve öğretmen arasındaki iletişimi arttırarak çocukların gelecekteki başarılarına 1şı tutan portfolyolar, aynı zamanda çocukların kendi öğrenmelerinin sorumluluklarını almalarına olanak sağlamakta, çocukların özgüvenlerini ve iletişim becerilerini de desteklemektedir (Seitz \& Barholomew, 2008). Bir diğer pedagojik dokümantasyon aracı olan bültenler ise öğretmenler tarafından hazırlanarak, ailelere çocukların öğrenme süreçleri hakkında bilgi vermeyi amaçlamaktadır. Bültenler mutlaka eğitici ve bilgilendirici olmalı, ailelere çocuk gelişimi hakkında bilgi verip, önerilerde bulunacak şekilde açık ve anlaşılır bir dil kullanılarak hazırlanmalıdır.

\section{Öğretmen Açısından Pedagojik Dokümantasyonun Önemi}

Öğretmenler, pedagojik dokümantasyon aracılığıyla çocuğun gelişimine dair objektif ve güvenilir bir değerlendirme yapma, çocuğun bireysel gelişimini ve büyümesini izleme ve eğitim programını değerlendirme imkânına sahip olurlar (Wien, Guyevskey, \& Berdoussis, 2011). Standart testler aracılığı ile yapılacak değerlendirmeler yerine pedagojik dokümantasyonun tercih edilmesi öğretmene, çocukların sınıf içerisindeki anlamlı öğrenmelerinin nasıl gerçekleştiğini görme ve 
sorumluluklarını yerine getirme firsatı sunar. Öğrenme süreçlerinin görünürlügünün sağlanması öğretmenlerin çocukların öğrenme süreçlerini çok iyi gözlemlemesine ve kaynakları etkili şekilde kullanmasına bağlıdır (Buldu, 2010).

Öğretmenlerin sınıfta tek lider ve tek karar veren kişi konumundan öğrenme süreçlerine dâhil olma boyutuna geçmeleri kolay değildir ancak pedagojik dokümantasyon süreci ile öğretmenler kendilerine eleştirel bir gözle bakıp, analiz yapmaya ve bunun sonucunda da kendilerini geliştirerek yeni uygulamalar planlamaya başlarlar (Wien, Guyevskey, \& Berdoussis, 2011).

Pedagojik dokümantasyon yönteminden yararlanan öğretmenler, dokümantasyonun temsil ettiği sorgulama sürecinin yalnızca sınıf ortamı ile sınırlı olmadığının bilincindedirler (Kline, 2008, Quinn \& Schwartz, 2011). Posta kutularına bırakılan notlar, öğretmen odasında masanın üzerine yayılmış videolar ve dinlenme zamanında koridorlarda yapılan konuşmalar, bunların hepsi öğretmenlerin keşiflerini, uygulamalarını, başarılarını ve başarısızlıklarını süreç içerisinde paylaşabileceği yollardır (Goldhaber \& Smith, 1997). Pedagojik dokümantasyon ayrıca, sınıf içerisindeki bireysel farklılıklara dikkat çekmek için de oldukça etkilidir. Farklı ilgi ve ihtiyaçlara sahip çocukların bir arada bulunduğu sınıflarda öğretmene etkili öğretim yapabilmesi için firsat oluşturur (Helm, Beneke, \& Steinheimer, 1998). Böylelikle, normal gelişim gösteren çocuklara olduğu kadar, özel gereksinimi olan çocuklar için de uygun öğrenme deneyimlerinin belirlenmesine destek olunur (Helm, Beneke, \& Steinheimer, 1998). Özetle, sınıf içerisindeki her türlü bireysel farklılıkların da başlı başına pedagojik dokümantasyon için bir ihtiyaç sebebidir. Öğretmenlerin ihtiyaç duyduğu, bütüncül bilgiyi sağlamayan standart değerlendirme yöntemlerinin aksine, nitelikli bir pedagojik dokümantasyon süreci öğretmenlerin, dezavantajlı ya da özel gereksinimi olan çocuklarla çalışırken verimli, yeterli ve gelişimsel olarak uygun kararlar alabilmelerinde destek olacaktır (Helm, Beneke, \& Steinheimer, 1998).

\section{Aile Açısından Pedagojik Dokümantasyonun Önemi}

Aileler çocuklarının okulda neler yaptıklarına dair bilgiler edinmekten hoşlanırlar pedagojik dokümantasyon bu açıdan onlar için oldukça önemli bir kaynaktır. Pedagojik dokümantasyon aracılığı ile öğretmenler ailelerle işbirliği geliştirerek aile katılımı çalışmalarına dâhil olmalarını sağlayabilir (Birbili \& Tzioga, 2014). Örneğin, dönem başından itibaren çocuğun yapmış olduğu ürünleri organize bir şekilde ebeveynlere sunan öğretmen, ailelerin çocuklarının gelişim sürecine tanıklık etmelerini sağlayabilir. Böylelikle öğretmen pedagojik dokümantasyon yolu ile ebeveynlerin çocuklarının gelişim sürecine ilişkin kaygılarını azaltıp çocuklarının doğal gelişim süreci, güçlü ve geliştirilmesi gereken yönleri hakkında bilgi verebilir. Çocuğunun gelişiminin takibini yapabilen aileler çocuklarının öğrenmeleriyle daha çok ilgilenirler ve okulda yürütülen çalışmalara katılmaya daha istekli olurlar (Helm, Beneke, \& Steinheimer, 1998; Kieff \&Wellhousen, 2000). Aileler hem evde hem de okulda yaşanılan deneyimleri birbirleriyle paylaşarak çocuklarının öğrenmelerine destek olmak için daha çok sorumluluk alırlar. Daha önce okulda yürütülen çalışmalara dâhil olmayan aileler dokümantasyon süreciyle birlikte okul sürecinin nasıl işlediği hakkında yeni bakış açıları elde eder ve daha çok katılım sağlama fırsatı bulurlar. Aileler okulda geçirdikleri zaman içerisinde çocuklarıyla daha fazla iletişimde bulunurlar ve çocukları hakkında daha fazla bilgi edinirler. Çocukları hakkında daha fazla bilgi sahibi olan 
aileler ise, çocuklarıyla ilgili daha derin bir anlayış edinir, çocuklarına daha çok saygı duyar, çocuklarının ilgilerine daha çok cevap verirler (Birbili \& Tzioga, 2014).

Helm, Beneke ve Steinheimer (1998) hem çocuklar hem öğretmenler hem de aileler için oldukça önemli olan pedagojik dokümantasyonun birden fazla türlerinin mevcut olduğunu belirtmişlerdir. Bunlar:

Çocuğun gelişiminin gözlemlenmesi: Anekdot kayıtları ve gelişim kontrol listelerinden oluşmaktadır

Çocuk öz değerlendirme: Ses-görüntü kayıtları, mizacın göstergeleri, bireysel ya da grupla iletişimi içerir.

Ürünler (bireysel ya da grup): Veriler, resimler, müzik/hareketle yapılan anlatımlar, oyun alanları, heykel, blok veya oyuncaklar, yazılı (kitaplar, harfler, etiketler, işaretler) ve sözlü ifadeler (hipotezler, sorular, tartışmalar), bağlantılardan oluşur.

Bireysel Portfolyo: Fotoğraflar, video-ses kayıtları, temel ürünler, bireyselleştirilmiş ürünleri içerir.

Proje anlatıları: Öğretmen günlükleri, personel-çocuk diyalog notları, çocuklar ve veliler için açıklamalar, sergi için açıklamalar şeklindedir.

Pedagojik dokümantasyon süreci gerçekleştirilirken izlenmesi gereken adımlar da oldukça önemlidir. Bu süreç içerisinde izlenmesi gereken adımlar aşağıda belirtildiği şeklindedir:

1. Öğretmenler, dokümantasyon sürecine, ilk olarak gerekli olabilecek materyalleri temin ederek başlayabilirler. Bu materyaller; gözlemleri kaydetmek için not defterleri, postitler, çocukların ürünlerini saklamak için klasörler, sınıfta veya sınıf dışı ortamda çocukların düşünce ve fikirlerini paylaşmalarına imkan tanıyan panolar, çocukların etkinlik sürecinde fotoğraflarını çekebilmek ve belgelemek için fotoğraf makinası, ses kayıt cihazı, kamera, her çocuk için mevcut materyalleri çoğaltabilmek için fotokopi makinası bilgisayar ve yazıcı gibi teknolojik aletler dokümantasyon sürecinde katkı sağlayacaktır (Helm, Beneke \& Steinheimer, 1998).

2. Dokümantasyon süreci içinde gerekli materyaller temin edildikten sonra takip edilen programın amaç ve kazanımlarını göz önünde bulundurmak önemlidir (Yu, 2008). Bu durum programda yer alan ve çocukların geliştirmesi beklenen becerilerin bilinmesi açısından önemlidir. Amaç ve kazanımlar belirlendikten sonra, öğretmen ne tür bir dokümantasyonla bu amaca ulaşacağına karar vermelidir (Helm, Beneke \& Steinheimer, 1998).

3. Amaç ve kazanımlara uygun dokümantasyon belirlendikten sonraki adım ise öğretmenin elde ettiği dokümantasyonla ne yapacağına karar vermesidir. $\mathrm{Bu}$ süreçte öğretmen kayıtları oluştururken elde edilen veriyi mümkün oldukça az sınırlandırmalıdır (Seitz, 2008). Elde edilen kayıtlar öğrenme süreci içinde farklı amaçlarla da kullanılabilmektedir. Bir diğer önemli nokta da herhangi bir öğrenme sürecinin en başında öğretmenlerin çocukların bilgi ve beceri düzeylerine ilişkin kayıt almasıdır (Helm, Beneke \& Steinheimer, 1998). Bunun için öğretmenler grafik, diyagram üzerinde süreç boyunca çocuklardaki değişimi kaydedebilir veya yazılı ya da sesli/görüntülü kayıtlar alarak süreç sonunda çocukların dil becerilerinde ve kelime dağarcıklarındaki ilerlemeyi de takip edebilir (Helm, Beneke \& Steinheimer, 1998) 
4. Öğretmenler genellikle dokümantasyonu yeni uygulamaya başladıklarında sınıfta olup biten her şeyi dokümante etmeye çalışma gibi bir yanılgıya düşerler ( Dahlberg, Moss \& Pence, 2007). Bu noktada öğretmenlerin bir ya da iki alana odaklanmaları daha kolay olabilir. Böylece öğretmen veri toplayacağı birkaç alanı belirleyip eğitim öğretim süreci boyunca hangi aralıklarla toplayacağına karar verebilir (Helm, Beneke \& Steinheimer, 1998).

5. Öğretmen, dokümantasyon sürecinin iki önemli unsurunu ( kayıt ve yansıtma) göz önünde bulundurarak uyguladığı belirli bir öğrenme alanındaki dokümantasyon çalışmasından sonra ne tür bir sergi ortaya çıkacağını öngörmek durumundadır (Helm, Beneke \& Steinheimer, 1998). Öğretmen zaman zaman serginin yerini değiştirmeli, sergilenen çalışmaları, yazılı ifadelerle desteklemelidir. Sergilenen ürünlerde yapılan çalışmanın önemi, çocukların neler öğrendikleri, neden böyle bir çalışmanın seçildiği, çocukların nasıl bir öğrenme sürecinden geçtiği, hem grup hem de bireysel olarak çocukların neler öğrendiği sergide yer almalıdır (Fleck ve ark. 2013; Helm, Beneke \& Steinheimer, 1998).

Pedagojik dokümantasyon sürecinin en önemli unsurlarından birini oluşturan öğretmenlerin pedagojik dokümantasyona ilişkin ilerlemeleri de oldukça önemli görülmektedir. Wien, Guyevskey \& Berdoussis, (2011) öğretmenlerin pedagojik dokümantasyona ilişsin ilerlemelerini beş basamak altında gözlemlemişlerdir. Bunlar

Belgeleme (dokümante etme) alışkanlıklarını geliştirme: Sınıfta kullanılacak araç-gereçlerin bir araya getirilmesi, öğretmenlerin dokümantasyon üzerine düşünme becerileri geliştirmeleri, çocukların sürekli gözlemlenmesi, önemli bir konuşmanın not alınması, ilk kez yapılan ya da önemli görülen bir anın fotoğraflanması.

Dokümantasyonların sunumunu başkaları ile paylaşmada rahat olma: Dokümantasyon sürecinin paylaşılması, daha nitelikli dokümantasyon yapabilmek için öğretmenin kendini geliştirmesine ve dokümantasyon üzerine düşünebilmesine katk1 sağlar. Yapılan çalışmaların paylaşılarak öğrenmenin görünür hale getirilmesi; başkalarının da yapılan çalışmalarla ilgili düşünce ve yorumlarını ifade etmesine olanak tanıyacaktır böylece dokümantasyon aracılığı ile öğretmenin profesyonel becerileri de topluma sunulmuş olacaktır.

Görsel okuryazarlık becerilerinin geliştirilmesi: Öğretmen görsel materyalleri kullanırken, bu materyalin başkaları tarafından işlevsel olarak okunabildiğine ve taşıdığı anlamın belirgin olduğuna emin olmalıdır. Görsel materyaller (yazı ve görüntü, hareketli ve hareketsiz görüntü, yazı ve ses) arasında bir denge kurulmalıdır.; her biri tek başına olduğundan daha iletişim odaklı olmalıdır.

Öğrenmeyi görünür kılmak için dokümantasyonu kullanma: Pedagojik dokümantasyon, aynı zamanda; öğretmenlere profesyonel gelişimi öğretme aracıdır. Öğretmenler dokümantasyon süreci ile çocukların öğrenme deneyimleri görünür hale getirirler. Çocukların yalnızca konuya ilişkin ürünlerini sergilemek yerine izleyicilere öğrenme sürecini yansitmak temel hedeftir.

Programın yorumlanması ve daha da geliştirilmesi için ortaya çıkan teorileri başkalarıla paylaşmadır. Dokümantasyon öğretim programını geliştirmede ve yönlendirmede etkili bir araçtır. Etkinlilerde ortaya çıkan teorileri açıkça gösteren dokümantasyon yaratarak, bu dokümantasyonun çocuklarla tekrar gözden geçirilmesini 
ve teorilerin tartışılmasını sağlamak, çocukları daha derin düşünmeye teşvik etmek için işbirliği yapmak oldukça önemlidir.

\section{Sonuç}

Okul öncesi dönemde çocukların tam anlamı ile desteklenebilmeleri için öğretmenlerin çocukların öğrenmelerindeki yeri şüphesiz oldukça önemlidir. Öğretmenlerin çocuklara zengin bir öğrenme ortamı oluşturabilmeleri için pedagojik dokümantasyonun sürecine hâkim olmaları gerekmektedir. Pedagojik dokümantasyon sürecinde çocuk, aile ve öğretmen işbirliğine, pedagojik dokümantasyon uygulamalarının başarılı şekilde gerçekleşmesi için ihtiyaç duyulmaktadır. Pedagojik dokümantasyon; çocuk, aile ve öğretmen arasındaki ilişkiyi güçlendirici ve aynı zamanda da hem çocuğu hem de öğretmeni ve aileyi destekleyici uygulamaları kapsamaktadır. Pedagojik dokümantasyon çocukların neler öğrendiklerinin adlandırılmasını ve müfredata bağlı kalınmasını sağlar. Çocuk, öğretmen ve ebeveyn arasında ortak bir anlayış oluşturularak gelecekteki öğrenme gereksinimlerini tam anlamıyla karşılayacak bir müfredat oluşturulur (Seitz, 2008). Pedagojik dokümantasyon ile öğretmenlerin, çocukların inşa ettiği konsepti, ortaya attıkları teorileri ve sordukları soruları anlamaları sağlanır (Fraser \& Gestwicki, 2012). Böylece öğrenme daha derin, kişisel ve bağlayıcı bir süreç halini alır. Çocukların duygu ve düşünceleri öğrenme sürecini derinden etkilemektedir. Öğretmenlerin çocuklarla kurdukları birebir ilişki çocukların öğrenme başarıları üzerinde doğrudan etkilidir. Pedagojik dokümantasyon stratejileri ile çocuğun ilgi alanları ve öğrenme gereksinimleri çocuk-öğretmen arasındaki kritik ilişkiyi kuvvetlendirebilir.

Sonuç olarak pedagojik dokümantasyon öğrenme için bir araçtır ve çocuk ve ebeveyn arasında bir köprü oluşturmaktadır. Pedagojik dokümantasyonun çocukların bütün gelişim alanlarını desteklemesi, öğretmen, çocuk ve aile arasında güvenli bağ oluşturması, olumlu iletişimi geliştirmesi, ailenin çocuğun öğrenme sürecine dâhil edilmesine destek olması, öğretmenin kendini değerlendirmesine firsat sunması, çocuğun öğrenme sürecine etkin katılımını sağlaması gibi yönleri ile okul öncesi eğitimde bir araç olarak kullanılması önemli görülmektedir. Alan yazın incelendiğinde de araştırmaların daha çok pedagojik dokümantasyonun çocuk ve öğretmen üzerindeki etkililiğini inceleyen çalışmalar olduğu ve pedagojik dokümantasyona ilişkin yapılmış olan ulusal yayınların ise oldukça sınırlı olduğu görülmüştür (Buldu, 2010; Fleck ve ark. 2013; McLellan, 2010; MacDonald, 2006; Rintakorpi \& Reunamo 2017). Böylece yapılan araştırmanın pedagojik dokümantasyona ilişkin derinlemesine bilgi sağlaması araştırmayı oldukça önemli kılmaktadır. Yapılan araştırmaların ve bu araştırmanın sonuçlarından yola çıkılarak okul öncesi eğitimde pedagojik dokümantasyonun öneminden yola çıkılarak okul öncesi öğretmenlerinin pedagojik dokümantasyon sürecini nasıl yöneteceğine ilişkin eğitimlerin verilmesine, pedagojik dokümantasyon sürecinin çocuklar ve ebeveynler üzerindeki etkisinden yola çıkılarak hem ailelerle hem de çocuklarla araştırmaların yapılması önemli görülmektedir. 


\section{Summary}

Initiatives aimed at supporting the child's development and adapting to the environment in early childhood are possible only by knowing the child. Developmental characteristics, socio-cultural and economic level of the family, interests, skills, attitudes, personality traits, peer relationships and strong and knowledgeable aspects of development should be supported to ensure maximum benefit to children from early childhood services. The process of recognizing the child is a multi-faceted process. In this process, it is very important that the information obtained about the child is kept confidential, the services for the recognition of the child are continued in different environments and at different times, the information obtained from one vehicle is used instead of the information obtained from one vehicle. Educators in the process of recognizing and evaluating the child; should not focus on what children cannot do, should focus on the process and cause of the behavior rather than on the consequences of the child's behaviors, should not ignore the individual differences among the children, and should conduct the evaluation studies absolutely in the ethical frame. Especially, it is very important for the children to be correctly identified and assessed in terms of the fact that the development of the children in the pre-school period is very rapid and the learning that takes place in this period forms the basis of future knowledge and skills. The recognition of children with all their qualities and support for their development with appropriate education draws attention to the quality of the education given to children both by themselves and by their families and educators. For this reason, it is very important to choose the tools and methods to be used in recognition and evaluation of the child in preschool period. In this study, the documentation review which is one of the methods used in the recognition and evaluation studies of the child is discussed. In the study, the phases of the documentation, the importance of the child, the teacher and the family, the types of documentation, the documentation process and finally the documentation of the teachers are mentioned. Documentation is an indispensable tool for creating positive experiences for children and facilitating professional development and communication for adults. There is an effort to provide evidence and communication for the situations we link with the documentation. It is an attempt to make a purposeful choice of observing and recording to think about and explain the surprising discoveries of children's everyday life and the extraordinary events they have in school. Documentation is not a separate and objective collection of data. Careful interpretation of the precise observations carried out by the trainers using various tools with different perspectives. Even in different forms, all children have the potential to learn and develop their own ideas, theories and strategies. All children have the right to be supported by adults in such initiatives. For this reason, teachers and parents need to listen to their observations and work. The most powerful tool that can be used to give children this support is the documentation that respects them as an individual. As a result, pedagogical documentation is a tool for learning. The pedagogical documentation supports all areas of development of children, creates a secure bond between teacher, child and family, develops positive communication, supports the involvement of the family in the child's learning process, provides the opportunity for the teacher to evaluate himself, and ensures the child's active participation in the learning process. Teachers should be able to manage the process of pedagogical documentation in order to create a rich learning environment for children.

(C) 2019 AKU, Kuramsal Eğitimbilim Dergisi - Journal of Theoretical Educational Science, 12(3), 935-949 
In the pedagogical documentation process, child, family and teacher cooperation is needed for the successful realization of pedagogical documentation practices. Pedagogical documentation; It includes practices that strengthen the relationship between the child, the family and the teacher, and also support the child as well as the teacher and the family. Pedagogical documentation allows children to name what they have learned. A common understanding is created between the child, teacher and parent to create a curriculum to overcome future learning needs. Pedagogical documentation enables teachers to understand the concept that children build, the theories they put forward, and the questions they ask. Thus learning becomes a deeper, personal and binding process. When the literature is examined, it is seen that the national and international publications on pedagogical documentation are very limited. Therefore, this research is very important to provide in-depth information about the pedagogical documentation. In this research, the importance of pedagogical documentation, types of documentation, importance, stages and teachers' understanding of documentation are mentioned. 


\section{Kaynakça}

Alcock, S. (2000). Pedagogical documentation: Beyond observations. Institute for Early Childhood Studies. Victoria University of Wellington. Wellington, New Zealand.

Alkan, C., \& Kurt, M. (2014). Özel öğretim yöntemleri \& disiplinlerin ögrretim teknolojileri. (4.bask1). Ankara: Anı Yayınc1l1k.

Beaty, J. (2006). Observing development of the young child (6th ed.). Columbus, OH: Pearson Merrill Prentice Hall.

Bowne, M., Cutler, K., DeBates, D., Gilkerson, D., \& Stremmel, A. (2010). Pedagogical documentation and collaborative dialogue as tolls of inquiry for pre-service teachers in early childhood education: An exploratory narrative. Journal of the Scholarship of Teaching and Learning, 10(2), 48-59. Retrieved from https://files.eric.ed.gov/fulltext/EJ890715.pdf

Buldu, M. (2010). Making learning visible in kindergarten classrooms: Pedagogical documentation as a formative assessment technique. Teaching and Teacher Education. 26, 1439-1449. https://doi.org/10.1016/j.tate.2010.05.003

Buldu, M., Şahin, F., \& Yılmaz, A. (2018). Okul öncesi dönem çocuklarının gelişim ve öğrenmelerinin desteklenmesinde pedagojik dokümantasyonun katkısının öğretmen görüşlerine göre incelenmesi. Illkögretim Online, 17(3), 1444-1462. https://doi.org/10.17051/ilkonline.2018.466365

Birbili, M., \& Tzioga, K. (2014). Involving parents in the children's assessment: lessons from the Greek context. Early Years 34(2), 161-174. https://doi.org/10.1080/09575146.2014.894498

Chen, J. Q., \& McNamee, G. (2006). Strengthening early childhood teacher preparation: Integrating assessment, curriculum development, and instructional practice in student teaching. Journal of Early Childhood Teacher Education, 27(2), 109-128. https://doi.org/10.1080/10901020600675083.

Dahlberg, G., Moss, P., \& Pence, A. (2007). Beyond quality in early childhood education and care: Postmodern perspectives. London, UK: Falmer.

Darling-Hammond, L., \& Bransford, J. (Eds.). (2005). Preparing teachers for a changing world: What teachers should learn and be able to do. San Francisco: Jossey Bass.

Deniz-Kan, Ü. (2007). Okul öncesi eğitimde değerlendirme aracı olarak portfolyo. Gazi Üniversitesi Gazi Ĕ̈itim Fakültesi Dergisi, 27(1), 169-178. Retrieved from http://www.gefad.gazi.edu.tr/download/article-file/77172

Edwards, C. P., \& Gandini, L. (2001). Bambini: The Italian approach to infant/toddler care. New York: Teachers College Press.

Fleck, B., Leichtman, M., Pillemer, D., \& Shanteler, L. (2013). The effects of documentation on young children's memory. Early Childhood Research Quarterly, 28, 568-577. https://doi.org/10.1016/j.ecresq.2013.03.001.

Forman, G., \& Hall, E. (2005, Fall). Wondering with children: The importance of observation in early education. Early Childhood Research and Practice, (7)2. Retrieved from http://ecrp.uiuc.edu/v7n2/forman.html

Fraser, S., \& Gestwicki, C. (2002). Authentic childhood: Exploring Reggio Emilia in the classroom. Canada: Delmar Thomson Learning. 
Gullo, D. F. (2005). Understanding assessment and evaluation in early childhood education. Teachers College Press, Amsterdam Avenue, New York, NY 10027.

Helm, J. H., Beneke, S., \& Steinheimer, K. (1998). Windows on learning. Documenting young children's work. New York: Teachers College Press.

Jablon, J. R., Dombro, A. L., \& Dichtelmiller, M. L. (2007). The power of observation for birth through eight (2nd ed.). Washington, DC: Teaching Strategies.

Kieff, J., \& Wellhousen, K. (2000). Planning family involment in early childhood programs. Young Children, 55, 18-25.

Kline, L.S. (2008). Documantation panel: The "making learning visible" project. Journal of Early Childhood Teacher Education, 29, 70-80. https://doi.org/10.1080/10901020701878685.

MacDonald, M. (2007). Toward formative assessment: The use of pedagogical documantation in early elementary classrooms. Early Childhood Research Quarterly, 22, 232-242. https://doi.org/10.1016/j.ecresq.2006.12.00

Malaguzzi, L. (1998). History, ideas, and basic philosophy. An interview with Lella Gandini. The Reggio Emilia approach to early childhood education (2nd ed). Greenwich, CT: Ablex Publishing Corporation.

McLellan, S. (2010). Pedagogical documentation as research in early mathematics. The Alberta Journal of Educational Research, 56(1), 99- 101. Retrieved from https://cdm.ucalgary.ca/index.php/ajer/article/view/55387

MEGEP (2015). Milli Ĕgitim Bakanlı̆̆ çocuk gelişimi ve eğitimi: Çocukları tanıma ve değerlendirme. $\quad$ Retrieved from http://www.megep.meb.gov.tr/mte_program_modul/moduller/\%C3\%87ocuklar\%C 4\%B1\%20Tan\%C4\%B1ma\%20-\%20De\%C4\%9Ferlendirme.pdf

NAEYC, National Association for the Education of Young Children. (2001). Standards for early childhood professional preparation. Retrieved from http://www.ncate.org/ /media/Files/caep/accreditation-resources/ncate-standards2008.pdf?la=en

Reynolds, B., \& Duff, K. (2016) Families' perceptions of early childhood educators' fostering conversations and connections by sharing children's learning through pedagogical documentation. Education 3-13, 44 (1), 93-100. https://doi.org/10.1080/03004279.2015.1092457.

Rintakorpi, K., \& Reunamo, J. (2017). Pedagogical documentation and its relation to everyday activities in early years. Early Child Development and Care, 187(11), 1611-1622. https://doi.org/10.1080/03004430.2016.1178637.

Seitz, H. (2008). The power of documentation in the early childhood education classroom. Young Children, 63(2), 88-93. Retrieved from https://www.naeyc.org/sites/default/files/globallyshared/downloads/PDFs/resources/pubs/seitz.pdf

Seitz, H., \& Bartholomew, C. (2008) Powerful portfolios for young children. Early Childhood Education Journal, 36(1), 63-68. https://doi.org/10.1007/s10643-0080242-7.

Thornton, L., \& Pat, B. (2014). Bringing the Reggio approach to your early years practice. London: Routledge. 
Trawick-Smith, J. (2013). Erken çocukluk döneminde gelişim (Çok kültürlü bir baklş açısı) (5. Baskı). (B. Akman, Çev.). Ankara: Nobel Akademik Yayıncılık.

Wien, C.A., Guyevskey, V., \& Berdoussis, N. (2011). Learning to document in Reggio inspired education. Early Childhood Research and Practice, 13(2), 1-12. Retrieved from http://ecrp.uiuc.edu/v13n2/wien.html

Yu, G. S. (2008). Documentation: Ideas and applications from the Reggio Emilia approach. Teaching Artist Journal, 6(2), 126-134. https://doi.org/10.1080/15411790801910735 